\title{
In memoriam: John Robert Glew (1942-2019)
}

\author{
John P. Smol 10
}

Received: 23 September 2019/Accepted: 10 October 2019/Published online: 3 November 2019

(C) Springer Nature B.V. 2019

It is with profound sadness that I report the passing of John R. Glew (Fig. 1) on 19 February 2019. He died unexpectedly in his sleep at his Kingston home. He was 76 years old.

John was born in Crookes, a district of Sheffield, England, on 15 October 1942. At a celebration of life held at Queen's University on 28 April 2019, his brother Peter Marshall-Glew recounted that from a very early age John showed promise in art and craftwork. When John left Secondary School in Crookes at the age of 15, he began a 7-year apprenticeship in Printing, Engineering and Design with Stephenson Blake \& Co., a type- and machine-tool foundry started in 1819, which became one of England's most prestigious operations. John learned his trade in precision tool making in the course of his 10 years at the foundry.

In 1967, John travelled to Montréal for Expo 67, originally as a holiday, but he quickly decided to stay in Canada. He first lived in Ottawa with the family of Ida Barr, a childhood friend of John's mother, who had emigrated as a war bride, but she continued to visit Sheffield regularly. Every year, she sent birthday and Christmas presents that, as John himself would

J. P. Smol $(\bowtie)$

Paleoecological Environmental Assessment and Research

Lab (PEARL), Department of Biology, Queen's

University, Kingston, ON K7L 3N6, Canada

e-mail: smolj@queensu.ca recount, promised a life much different from that of post-war Britain. John soon found work in Ottawa with Sperry Gyroscope Corporation, which evolved into a company that manufactured precision electronic equipment for the naval and aircraft industries. It was a natural fit for John, and he remained there until persuaded by the Barr family that he might want to try university.

In 1974, John enrolled in a Bachelor of Science program in Geography at Trent University (Peterborough, Ontario) as a mature student and was taken under the wing of the late Peter Adams. He graduated and then completed a Bachelor of Education at Queen's University (Kingston, Ontario). He then taught for a few years in Northern Ontario before enrolling as an MSc student at McMaster University (Hamilton, Ontario), where he received a degree in physical geography. When in his 40s, John returned to Queen's University as a PhD student in the Department of Geography.

It was in the Department of Geography that I initially met John, within a few days of receiving my professorship. Our first meeting was at his "desk" (actually a large drafting table) in an office that he shared with other graduate students. He was easy to pick out from his student cohort - partly by his age (he being about 20 years older), but also in contrast to everyone else in the room who had books and journals on their desk, John was inking a large technical 


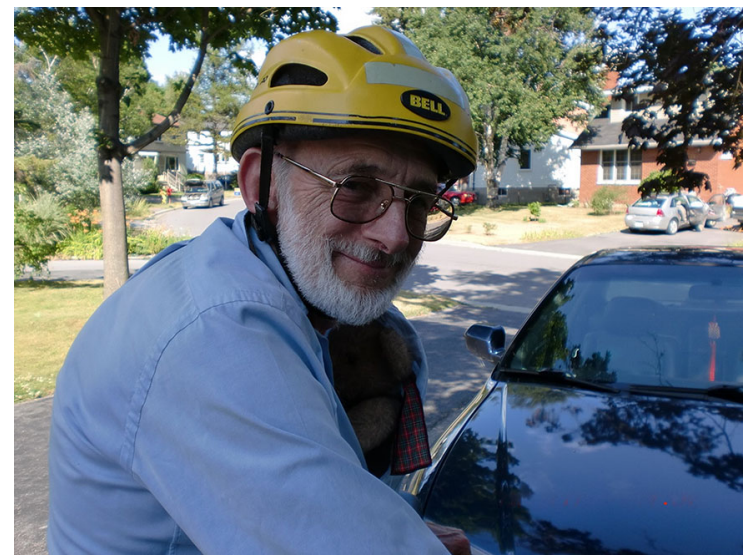

Fig. 1 John R. Glew (1942-2019). Photograph by Xiaoyin Liu

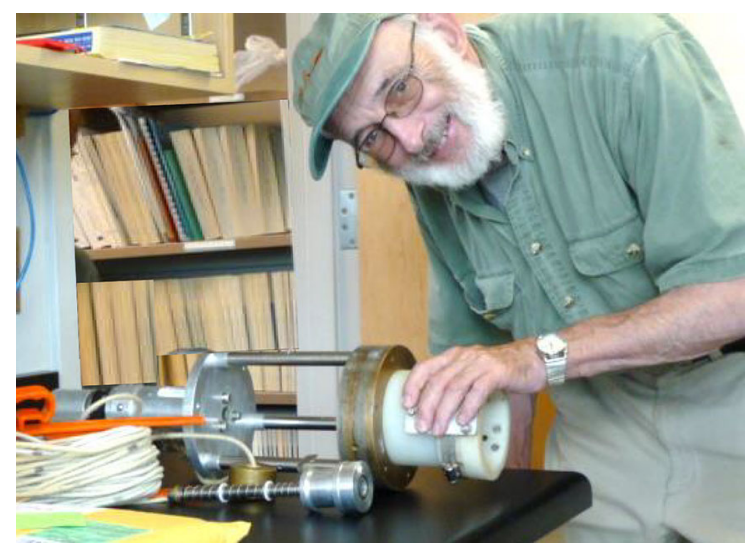

Fig. 2 John Glew with the Glew gravity corer. Photograph by K. Rühland

drawing, surrounded by bits and pieces of electrical apparatus. He was already designing new equipment-in this case a prototype of an underwater camera that would be used to study sediment movement and marine organisms at the bottom of Pangnirtung Fjord, in the eastern Canadian Arctic.

Following our first meeting, we became friends and John started visiting our young, but rapidly expanding paleolimnology lab. His interest in his doctoral research waned, and shortly afterward he began working with me and colleagues at the Paleoecological Environmental Assessment and Research Lab (PEARL), designing and building specialized equipment, and making remarkable technical drawings. John's rare combination of creativity and technical skills, coupled with his understanding of the physics and mechanical details of sediment coring and extrusion, were key to the success of his many designs. All of his devices were constructed in his garage, or what John would call "the Hatter Street Centre of Excellence," using pre-1960s machines that he had carefully sourced and collected over many years.

John is best known for his various "Glew" sediment corers (Fig. 2) and extruders (first designed for our early acid rain work, which required highresolution records of lake ecosystem changes). These instruments included the original Glew (1989) gravity corer and Glew (1988) extruder. The mini-Glew corer (Glew 1991) followed, which proved especially useful for our research in the High Arctic, allowing us to core through a single ice auger hole, and it largely replaced the other small sediment corers that were often unreliable. The mini-Glew corer has also been invaluable in the development of surface-sediment calibration datasets and research involving multiple cores from a single lake. He later modified his designs with adaptations for deep-water (Glew 1995) and then shallow-water (Glew and Smol 2016) coring. He was very innovative in other aspects of developing coring equipment, including the modification of the pressurerelease valves of various piston corers. He co-authored summaries of the overall protocols and challenges of sediment coring (e.g. Cumming et al. 1993; Glew et al. 2001) that remain valuable sources for newcomers and seasoned paleolimnologists alike.

John's paleolimnological equipment is in use on all seven continents. He was an inaugural winner of the International Paleolimnology Association Service Award, which was presented in Glasgow in 2012 for "dedicated work in developing and improving new corers and samplers used by paleolimnologists worldwide".

John's remarkable mechanical skills were also indispensable in the field. For many of my High Arctic field seasons, he was my right hand (and often my left hand as well). He could fix almost anything, from field gear, small motors, electrical equipment, to infrastructure torn apart by polar bears!

In addition to his technical and creative skills, John was an accomplished artist, working mainly in watercolours. John's artistic talent, combined with his geological knowledge, provided him with a unique skill set that brought to life complex landscape processes that he captured beautifully. It was John who, in 1987, developed the cover logo for the Journal of Paleolimnology, still in use today, as well as the 


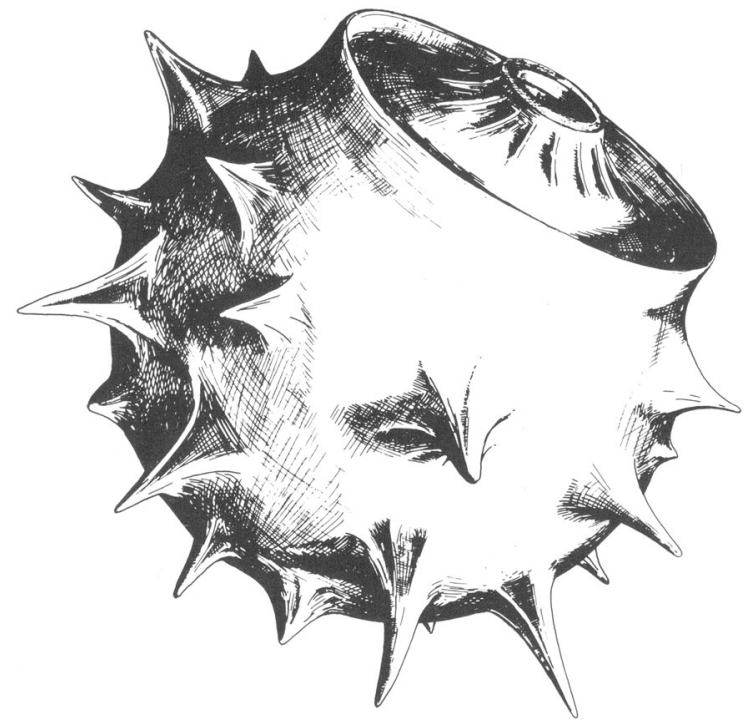

Fig. 3 One of the many scientific illustrations drawn by John Glew, in this case one of the chrysophyte stomatocyst morphotypes used in the Duff et al. (1995) cyst atlas

logo for the International Paleolimnology Association. John illustrated all of my books, notably the two volumes of the chrysophyte cyst atlas (Fig. 3; Duff et al. 1995; Wilkinson et al. 2001), and my paleolimnology textbook (Smol 2008), amongst other volumes.

John's skills, curiosity and creativity made him an invaluable resource and a unique mentor. He was a friend to many students and could supply just the right piece of equipment, whether it be his own invention or a rescued object. John easily befriended people from around the world and from all walks of life. He had a great sense of humour, and as one of his friends aptly said, he had a keen interest in politics and society and took every chance to "put the world to rights", often with funny anecdotes. His curiosity never waned. For example, in retirement he studied Japanese and visited Japan frequently. He could often be seen in his yellow bicycle helmet riding to campus (in all seasons, including Canadian winters!) or having coffee with one of his many friends.

John officially retired a few years ago, but continued on as a part-time employee at PEARL, where we saw him almost every day, regaling the lab with his "distinct view on life". John Glew was a unique individual who enriched the lives of all who knew him well.

In April, about 100 former students, colleagues, and friends, some coming from as far away as the Yukon
Territory and the Pacific coast of Canada, returned to Queen's University for a celebration of John's life. It seemed ironic to have the celebration in the large Biosciences Atrium-most visitors compliment the facility as a beautiful, wide-open space decorated with artwork, but John could not walk through the atrium without grumbling that "the administration claims they have no resources for a decent workshop, but they have money to build a big "useless" atrium!" For $2 \mathrm{~h}$, people laughed and cried as anecdotes about John's colourful life were presented. These included stories about how John never gave directions using street names, but instead used geological features (for example, "turn right at the first metamorphic outcrop"), assuming everyone would understand these "obvious" landmarks. I also recalled the time when John was preparing to travel to the south of France for a student's wedding. I suggested he take one of my travel books on France as a guide (this was before the advent of smartphones and online resources), and I pointed out that there was a map in the book of each town he would visit, so he could orient himself easily. John interjected "But I am all set. I do have a map!" He then slowly unrolled an enormous map entitled the Soils of France, a map that had no cities listed, no train lines, no roads-it was just a soil map of France! Of course the first reaction was to laugh, but when I thought about it more, John knew the land so well, I could almost imagine him arriving in a village in France, examining some of the soil between his fingers and saying "Hmm, interesting combination of chalk, sand, gravel, clay and limestone-I must be in the Loire Valley!"

I had coffee with John at my home hours before he died, and he was argumentative and entertaining as usual. After commenting on the substandard quality of the cookies I had offered him, his parting words were "Take care Johnnie, I have to go home and feed the cats." He strapped on his yellow helmet and rode his bicycle home. He was my closest friend and sharpest critic for 35 years.

John is survived by his brother, Peter MarshallGlew, of Victoria (British Columbia), and Peter's family, as well as hundreds of friends. He is sorely missed by all who knew him. 


\section{References}

Cumming BF, Glew JR, Smol JP, Davis R, Norton S (1993) A comment on "Core compression and surficial sediment loss of lake sediments of high porosity caused by gravity coring". Limnol Oceanogr 38:695-699

Duff K, Zeeb B, Smol JP (1995) Atlas of chrysophycean cysts. Kluwer Academic Publishers, Dordrecht

Glew JR (1988) A portable extruding device for close interval sectioning of unconsolidated core samples. J Paleolimnol 1:235-239

Glew JR (1989) A new trigger mechanism for sediment samplers. J Paleolimnol 2:241-243

Glew JR (1991) Miniature gravity corer for recovering short sediment cores. J Paleolimnol 5:285-287

Glew JR (1995) Conversion of shallow water gravity coring equipment for deep water systems. J Paleolimnol 14:83-88
Glew JR, Smol JP (2016) A push corer developed for retrieving high-resolution sediment cores from shallow waters. J Paleolimnol 56:67-71

Glew JR, Smol JP, Last WM (2001) Sediment core collection and extrusion. In: Last WM, Smol JP (eds) Tracking environmental change using lake sediments, vol 1. Basin analysis, coring, and chronological techniques. Kluwer Academic Publishers, Dordrecht, pp 73-105

Smol JP (2008) Pollution of lakes and rivers: a paleoenvironmental perspective, 2nd edn. Wiley, Oxford

Wilkinson AN, Zeeb B, Smol JP (2001) Atlas of chrysophycean cysts, vol II. Kluwer Academic Publishers, Dordrecht

Publisher's Note Springer Nature remains neutral with regard to jurisdictional claims in published maps and institutional affiliations. 